\title{
TRACHELOMONAS HINDAKII NOM. NOV. (EUGLENOPHYTA)
}

\author{
KonRad Wolowski \& Kritsana DuAngJan
}

Konrad Wolowski, Department of Phycology, W. Szafer Institute of Botany, Polish Academy of Sciences, Lubicz 46, $31-512$ Kraków, Poland; e-mail: k.wolowski@botany.pl

Kritsana Duangjan, Department of Biology, Faculty of Science, Chiang Mai University, Chiang Mai, Thailand; e-mail: vvb_hunter @hotmail.com

During elaboration of new taxa of Trachelomonas reported from Thailand (Wołowski \& Duangjan 2013), Trachelomonas hystrix Teilings var. paucispinosa Prowse was elevated to species rank, under the name Trachelomonas paucispinosa (Prowse) Duangjan \& Wołowski. This name is illegitimate, however, as it is later homonym of Trachelomonas paucispinosa Playfair (Playfair 1915). Hence the need for a new name for Trachelomonas hystrix var. paucispinosa Prowse as follows:

Trachelomonas hindakii Duangjan \& Wołowski, nom. et stat. nov.

BASIONym: Trachelomonas hystrix Teilings var. paucispinosa Prowse, Gard. Bull. Singapore 16: 183, Figures $6 b_{1}, c_{1} .1958$.

Trachelomonas paucispinosa (Prowse) Duangjan \& Wołowski, Polish Bot. J. 58(1): 341. 2013, nom. illeg. (later homonym of Trachelomonas paucispinosa Playfair 1915).
NoTE. For detailed description, illustration and discussion see Duangjan and Wołowski (2013).

ETYMology. Named in honor of the eminent Slovak phycologist Professor František Hindák, for his many and varied contributions to world phycological research.

ACKNOWLEDGEMENTs. I am grateful to Marcin Piątek for helpful suggestions. The work of the authors was supported by statutory founds of the W. Szafer Institute of Botany, Polish Academy of Sciences, Kraków, Poland.

\section{REFERENCES}

DuAngJan K. \& Wolowski K. 2013. New taxa of loricate euglenoids Strombomonas and Trahelomonas from Thailand. Polish Bot. J. 58(1): 337-345.

Playfair G. I. 1915. The genus Trachelomonas. Proc. Linn. Soc. New South Wales 40: 1-41.

Prowse G. A. 1958. The Eugleninae of Malaya. Gard. Bull. Singapore 16: 136-204. 